\title{
Clinical Characterics, Laboratory Features, and Management of Odontogenic Facial Cellulitis
}

\author{
Diş Kaynaklı Fasiyal Selülit Olgularının Klinik, \\ Laboratuvar Özellikleri ve Tedavi Yönetimi
}

\author{
Ayşe Kaman', Türkan Aydın Teke', Fatma Nur Öz', Gülsüm İclal Bayhan², Özge Metin, Zeynep Gökçe Gayretli Aydın \\ Sevgi Yaşar Durmuş̧', Gönül Tanır' \\ ${ }^{1}$ Clinic of Pediatric Infectious Diseases, Dr. Sami Ulus Obstetrics and Gynecology and Pediatrics Training and Research Hospital, Ankara, Turkey \\ ${ }^{2}$ Department of Pediatric Infectious Diseases, Yildirim Beyazit University School of Medicine, Ankara, Turkey \\ ${ }^{3}$ Department of Pediatric Infectious Diseases, Necmettin Erbakan University School of Medicine, Konya, Turkey \\ ${ }^{4}$ Department of Pediatric Infectious Diseases, Karadeniz Technical University School of Medicine, Trabzon, Turkey
}

\begin{abstract}
Objective: Dental caries remain one of the most common chronic diseases in childhood, globally. The purpose of this study is to determine clinical characteristics and treatment modalities of pediatric patients with odontogenic facial cellulitis.
\end{abstract}

Material and Methods: Medical records of children with odontogenic facial cellulitis hospitalized in pediatric infectious disease clinic were analyzed retrospectively between January 2013 and December 2017.

Results: Ninety-eight patients ( 43 girls, 55 boys) with median age of 86 months (min-max: 19-207 months) were evaluated. Forty-five (45.9\%) patients had no regular toothbrushing habits. Forty-eight $(48.9 \%)$ patients had no any dental treatment procedure history. Eighteen (18.3\%) patients had never recoursed to a dentist. Seventy-five patients (76.5\%) were diagnosed with odontogenic facial cellulitis for the first time. Four patients (4\%) were hospitalized with the same diagnosis previously. On admission, 37 (37.8\%) patients had fever. On admission, the mean white blood cell (WBC) count, erythrocyte sedimentation rate, and C-reactive protein (CRP) were $11.981 \pm 4.433 / \mathrm{mm}^{3}, 29.1 \pm$ $17.6 \mathrm{~mm} / \mathrm{h}$ and $35.2 \pm 39.4 \mathrm{mg} / \mathrm{L}$, respectively. The mean duration of intravenous antibiotic treatment was $5.5 \pm 2.5$ days, and total medical treatment was $12.5 \pm 2.9$ days. Ampicillin-sulbactam was started to 82 (83.7\%) of the patients. Clindamycin was added to 15 (15.3\%) patients. Increased mean WBC count on admission was correlated with duration of hospital stay $(p=0.036)$, while increased CRP level was correlated
Özet

Giriş: Diş çürükleri, dünya çapında en yaygın kronik hastalıklardandır. Bu çalışmanın amacı diş kaynaklı fasiyal selülit nedeniyle hastaneye yatırılan çocuk hastaların klinik özelliklerinin ve tedavi yöntemlerinin değerlendirilmesidir.

Gereç ve Yöntemler: Bu çalışmada, diş kaynaklı fasiyal selülit tanısı ile Ocak 2013-Aralık 2017 tarihleri arasında çocuk enfeksiyon hastalıkları servisinde yatırılarak takip edilen hastaların diş sağlığına ilişkin öyküleri, klinik ve laboratuvar özellikleri ile tedavi şekilleri geriye dönük olarak değerlendirildi.

Bulgular: Çalışmaya ortanca yaşları 86 ay (min-maks: 19-207 ay) olan 98 (43 kız, 55 erkek) hasta alındı. Hastaların 45 (\%45.9)'inin düzenli diş fırçalama alışkanlığı yoktu. Kırk sekiz (\%48.9) hastanın herhangi bir diş tedavisi öyküsü yoktu. On sekiz (\%18.3) hasta hiç diş hekimine başvurmamıştı. Hastaların 75 (\%76.5)'i ilk kez diş kaynaklı fasiyal selülit tanısı alırken, 4 (\%4)'ü daha önce aynı tanıyla hastanede yatırılmıştı. Otuz yedi (\%37.8) hastanın başvuruda ateşi vardı. Hastaların başvurudaki ortalama beyaz küre sayısı $11.981 \pm 4.233 / \mathrm{mm}^{3}$, eritrosit sedimentasyon hızı $29.1 \pm 17.6 \mathrm{~mm} /$ saat ve C-reaktif protein (CRP) değeri $35.2 \pm 39.4 \mathrm{mg} / \mathrm{L}$ olarak saptandı. Ortalama intravenöz (IV) antibiyotik tedavi süresi $5.5 \pm$ 2.5 gün, toplam antibiyotik tedavi süresi $12.5 \pm 2.9$ gündü. Hastaların 82 (\%83.7)'sine ampisilin-sulbaktam başlanmıştı. On beş (\%15.3) hastanın
Correspondence Address / Yazışma Adresi

Ayşe Kaman

Dr. Sami Ulus Kadın Doğum Çocuk Sağlığı ve Hastalıkları Eğitim ve Araştırma Hastanesi, Çocuk Enfeksiyon Hastalıkları Kliniği, Ankara-Türkiye

E-mail: ayse092003@yahoo.com OCopyright 2018 by Pediatric
Infectious Diseases Society -Available online at www.cocukenfeksiyon.org OTelif Hakkı 2018 Çocuk Enfeksiyon Hastalıkları Derneği -Makale metnine www.cocukenfeksiyon.org web sayfasından ulaşılabilir 
Kaman et al.

with total medical treatment duration $(p=0.032)$. Patients who received clindamycin had longer duration of intravenous and total medical treatment $(p<0.001$ and $p<0.001)$.

Conclusion: If dental caries are not recognized and treated immediately, they may spread into surrounding connective tissue as cellulitis and may lead to hospitalization in young patients. Oral health is a mainstone of life-long well-being, so oral health problems should be considered as a major public health problem and preventive measures should be taken to improve oral health.

Keyword: Child, dental caries, facial cellulitis

\section{Introduction}

Oral health is an integral part of an individual's overall health. Poor oral health and dental caries which is one of the most common chronic diseases worldwide, take place as the fourth disease in the treatment cost ranking (1). In the United States, dental caries are the most common chronic disease in childhood. The incidence of dental caries is 5 times higher than that of bronchial asthma (2). According to the Centers for Disease Control and Prevention data, 96\% of adults aged 65 years or older in the United States have a history of dental caries in their permanent teeth. The prevalence of untreated dental caries in children according to age groups; $6.1 \%$ in children between 6-11 years of age, $14.5 \%$ in children between $12-15$ years of age and $22.6 \%$ in children between $16-19$ years of age (3). According to data from the Turkey Statistical Institute in 2016, oral and dental diseases are among the first five diseases in the last 6 months in children aged 0-6, and in the 7-14 age group ranks in the first with $23.4 \%$ (4). Dental-induced infections, which are usually mild, can be easily treated with oral antibiotics. However, hospitalization may be required for incision, drainage and/or intravenous antibiotic therapy of the abscess when the infection is serious (5). Odontogenic facial cellulitis is cellulite caused by teeth and auxiliary periodontal structures. If the treatment of odontogenic facial cellulitis is not performed at the appropriate time and with the appropriate agent; sepsis may lead to systemic and life-threatening complications such as central nervous system infection and airway obstruction $(6,7)$. Therefore, it is necessary to approach oral health problems as a public health problem and produce solutions.

The aim of this study was to evaluate the history of dental caries and dental health follow-up, clinical characteristics and treatment methods of the pediatric patients hospitalized due to the diagnosis of dental facial cellulitis.

\section{Materials and Methods}

In this study, the patients who were hospitalized in the infant service between January 2013 and December 2017 with tedavisine klindamisin eklenmişti. Başvurudaki beyaz küre sayısı arttıkça hastanede yatış süresinin arttığı $(p=0.036)$ ve yüksek CRP düzeyi olanlarda toplam medikal tedavi süresinin arttığı saptandı $(p=0.032)$. Tedavisine klindamisin eklenen hastaların IV ve toplam tedavi süresinin daha uzun olduğu saptandı $(p<0.001$ ve $p<0.001)$.

Sonuç: Diş çürükleri erken tanınıp tedavi edilmediği takdirde ilerleyerek selülite ve çocuklarda hastaneye yatışa neden olabilir. Hayat boyu temel sağlığın ayrıımaz bir parçası olan ağız sağlığının iyileştirilmesi için koruyucu önlemler alınmalı ve diş sağlığı sorunlarına bir halk sağlığı sorunu olarak yaklaşılmalıdır.

Anahtar Kelimeler: Çocuk, diş çürükleri, fasiyal selülit

the diagnosis of dental facial cellulite were evaluated retrospectively. The study was approved by the Ethics Committee of Keçiören Education and Research Hospital Ethics Committee with the decision number 2018/1651. Age, sex, feeding history, tooth brushing behaviors, parental brushing behaviors, number of dental visits, number of dental caries, number of dental treatment, presence of fever history $\left(38^{\circ} \mathrm{C}\right.$ with tympanic fever gauge), location of infection (upper right, upper left, right lower and left lower), presence of preceptal cellulitis, total leukocyte count at the time of admission and on the fourth day of hospitalization, platelet count, erythrocyte sedimentation rate $(\mathrm{ESH})$ and C-reactive protein (CRP), if any, antistreptolizin-O (ASO) levels, length of hospitalizaiton, outpatient and inpatient antibiotic treatment and total antibiotic treatment time of the patients were recorded. The reference range in our patients according to the laboratory values of our hospital; 0-4 mg/L for CRP, 0-10 mm/hr for ESH and 0-200 IU/ $\mathrm{mL}$ for ASO.

Infections were classified as right/left upper face or right/ left lower face according to their anatomical location. Upper-face infections were defined as the cellulite maxillary teeth-induced in periorbital, maxillary, frontal, nasal or upper cheek regions, including the areas on the lip line. Lower face infections were defined as the cellulite mandibular tooth-induced under the lip line including the mouth floor and cervical region. Right face and left face infections were defined as the cellulitis inducing from the right or left side of the facial line.

Statistical analysis was conducted with IBM SPSS for Windows Version 22.0 Armonk, NY: IBM Corp. package program. Numerical variables were represented as mean \pm standard deviation or median [minimum-maximum] values. Categorical variables were indicated by number and percentage. The chisquare test was used to determine whether there was any difference between the groups in terms of categorical variables. The Kolmogorov Smirnov test was used to determine whether the numerical variables showed normal distribution, and the homogeneity of the variance was studied with the Levene 
test. Differences between two independent groups were investigated with Mann-Whitney $U$ test in terms of numerical variables which do not show normal distribution. Kruskal-Wallis test was used to compare more than two independent age groups. Spearman correlation coefficient was used to investigate the relationship between numerical variables. T-test or Wilcoxon test was used to determine in the dependent groups whether there was any difference between admission and control laboratory values of the patients. Significance level was taken as $p<0.05$.

\section{Results}

A total of 98 patients admitted to the hospital with a diagnosis of dental facial cellulitis were included in the study. The median age was 86 months (min-max: 19-207 months) and the mean age was $89.46 \pm 37.82$ months. Sixteen patients
(16.3\%) were under 5 years of age, 65 (66.3\%) were between 5 and 10 years, and 17 (17.3\%) were older than 10 years. 43 (43.9\%) of the patients were female and $55(56.1 \%)$ were male. Fifty-four patients $(55.1 \%)$ were directed by a dentist to administer antibiotic therapy. The $15(15.3 \%)$ of the patients had a chronic disease: [4 (4.08\%) had operated congenital heart disease, 3 (3.06\%) had asthma, 1 (1.02\%) had dilated cardiomyopathy, 1 (1.02\%) had congenital adrenal hyperplasia, 1 (1.02\%) had epilepsy, 2 (2.04\%) had mental and motor retardation, $1(1.02 \%)$ had growth hormone deficiency, 1 (1.02\%) had hypothyroidism and $1(1.02 \%)$ had selective immunoglobulin A deficiency]. Information about feeding habits, brushing habits, follow-up of the dentist, follow-up of dental treatment of the patients and information about the brushing habits of the parents are summarized in Table 1.

Table 1. Nutrition and dental health follow-up characteristics of patients

\begin{tabular}{|c|c|c|c|}
\hline Study variable & Data n (\%) & Study variable & Data n (\%) \\
\hline \begin{tabular}{|l} 
Consumption of sugared food/day \\
Never consumed \\
1 time/day \\
2 times/day \\
3 times/day \\
$>3$ times/day \\
\end{tabular} & $\begin{array}{c}3(3) \\
22(22.4) \\
26(26.5) \\
14(14.2) \\
33(33.6)\end{array}$ & $\begin{array}{l}\text { Number of dental caries } \\
\text { One filled teeth } \\
\text { Two filled teeth } \\
\text { Three filled teeth } \\
\text { > Three filled teeth }\end{array}$ & $\begin{array}{l}14(14.2) \\
31(31.6) \\
16(16.3) \\
37(37.7) \\
\end{array}$ \\
\hline $\begin{array}{l}\text { Tooth brushing start age } \\
\text { Between } 24-48 \text { months } \\
\text { Between } 49-60 \text { months } \\
\text { Between } 61-72 \text { months } \\
\text { Between } 73-84 \text { months } \\
\geq 85 \text { months } \\
\text { Never brushed } \\
\end{array}$ & $\begin{array}{c}38(38.7) \\
21(21.4) \\
14(14.2) \\
9(9.1) \\
8(8.1) \\
8(8.1)\end{array}$ & $\begin{array}{l}\text { Number of filled teeth } \\
\text { No filled teeth } \\
\text { One filled teeth } \\
\text { Two filled teeth } \\
\text { Three filled teeth } \\
\text { > Three filled teeth }\end{array}$ & $\begin{array}{c}62(63.2) \\
12(12.2) \\
9(9.1) \\
7(7.1) 8 \\
(8.1)\end{array}$ \\
\hline $\begin{array}{l}\text { Frequency of teeth brushing/day } \\
\text { Doesn't brush every day } \\
\text { Only morning } \\
\text { Only evening } \\
\text { Morning-Evening } \\
\text { Morning-noon-evening }\end{array}$ & $\begin{array}{l}45(45.9) \\
10(10.2) \\
13(13.2) \\
28(28.5) \\
2(2)\end{array}$ & $\begin{array}{l}\text { Dentist application number } \\
\text { Once } \\
\text { Two times } \\
\text { Three times } \\
\text { > Three times } \\
\text { No application }\end{array}$ & $\begin{aligned} 16 & (19.2) \\
13 & (15.6) \\
3 & (3.6) \\
33 & (39.7) \\
18 & (21.6)\end{aligned}$ \\
\hline $\begin{array}{l}\text { Tooth brushing time } \\
\text { After meals } \\
\text { Before bedtime } \\
\text { Before meals and after bedtime } \\
\text { Never brushes }\end{array}$ & $\begin{array}{c}37(37.7) \\
28(28.5) \\
25(25.5) \\
8(8.1)\end{array}$ & $\begin{array}{l}\text { Number of dental treatment } \\
\text { Once } \\
\text { Two times } \\
\text { Three times } \\
\text { > Three times } \\
\text { No treatment }\end{array}$ & $\begin{aligned} & 16(16.3) \\
& 9(9.1) \\
& 8(8.1) \\
& 17(17.3) \\
& 48(48.9)\end{aligned}$ \\
\hline $\begin{array}{l}\text { Tooth brushing duration } \\
30 \text { seconds } \\
1 \text { minute } \\
1.5 \text { minutes } \\
2 \text { minutes } \\
>2 \text { minutes }\end{array}$ & $\begin{array}{l}19(21.1) \\
36(40) \\
10(11.1) \\
13(14.4) \\
12(13.3)\end{array}$ & $\begin{array}{l}\text { Parents' brushing condition } \\
\text { Brushes } \\
\text { Never brushes }\end{array}$ & $\begin{array}{l}86(87.7) \\
12(12.2)\end{array}$ \\
\hline
\end{tabular}


Seventy-five patients (76.5\%) were diagnosed with dental facial cellulitis for the first time, while 23 patients (23.5\%) had previously experienced dental abscess. Four of the 23 patients (17.3\%) who had undergone dental abscess were hospitalized with similar diagnosis before. Thirty-seven (37.8\%) of the patients had fever complaints when they consulted to the hospital. Mean duration of fever was $2.1 \pm 3.1$ days and median duration of fever was 2 days (min-max: 1-20 days) in patients with fever. There was no significant relationship between the presence of fever and age of the patients at admission ( $p=$ $0.971)$. Twenty-three $(23.5 \%)$ of the patients had cellulite and swelling in the left lower jaw, 26 (26.5\%) had in the left upper jaw, 23 (23.5\%) had in the right lower jaw and 26 (26.5\%) had in the right upper jaw. Thirty-four (34.7\%) patients had preceptal cellulitis accompanying facial cellulitis. There was no significant relationship between the age of the patients and the presence of preseptal cellulitis $(p=0.667)$.

Forty-three $(43.9 \%)$ of the patients had undergone antibiotic treatment for dental facial cellulitis before hospitalizaiton. The mean duration of antibiotic use of the patients was 3.9 \pm 3.4 days (min-max: 1-15 days) before admission. Antibiotics used prior to hospitalization are; amoxicillin-clavulonic acid combination by $36(36.7 \%)$ patients, amoxicillin by two (2\%) patients, intramuscular ceftriaxone by two (2\%) patients, clindamycin with cefuroxime-axetil by one (1\%) patient, and clindamycin by $1(1 \%)$ patient and oral ampicillin-sulbactam by one (1\%) patient. There was no relationship between the presence of antibiotic use before admission and the duration of intravenous therapy and total medical treatment $(p=0.312$ and $p=0.365$ ).

Laboratory findings taken on hospital admission and on the 4th day of hospitalization as a control are summarized in Table 2. Fifty-eight (59.1\%) patients underwent ASO once and $28(48.2 \%)$ of these patients had ASO values higher than the normal reference range (mean ASO: $286.6 \pm 274.8 \mathrm{IU} / \mathrm{mL}$, minmax. $25-1260 \mathrm{IU} / \mathrm{mL}$ ). On the $4^{\text {th }}$ day of hospitalization, the mean platelet count was found to be significantly increased ( $p$ $=0.014)$, and the control white blood cell and CRP values decreased significantly $(p<0.001$ and $p<0.001$, respectively). No significant difference was found between initial and control ESR values $(p=0.264)$. There was no significant relationship between the presence of fever and the white blood cell count, ESR and CRP values at the time of admission $(p=0.081, p=0.335$ and $p=0.060$, respectively). There was no significant relationship between preceptal cellulite presence and initial white blood cell, ESR, CRP and ASO levels ( $p=0.253, p=0.117, p=0.113$ and $p=0.265$, respectively).

Intravenous antibiotic treatment was started in all patients. The mean hospitalization and duration of intravenous antibiotic use were $5.5 \pm 2.5$ days (min-max: 3-16 days). All patients were discharged with oral sequential antibiotics. The mean duration of oral sequential antibiotic treatment was $7 \pm 1.5$ days (min-max: 4-14 days), and the total antibiotic treatment period was averagely $12.5 \pm 2.9$ days (min-max: 8-26 days). Intravenous antibiotics started in hospital are shown in Table 3 and oral sequential antibiotics prescribed after discharge is shown in Table 4. Three patients underwent abscess drainage. Vancomycin was added to the treatment after Streptococcus viridans which was resistant to ampicillin and ceftriaxone and sensitive to vancomycin and teicoplanin was detected in the drainage culture of a patient. There was no reproduction in abscess culture of two patients. Clindamycin treatment was added to the initial antibiotics treatment of 15 patients (15.3\%) because there was no clinical response or progress under the beta-lactam antibiotics treatment. In patients whose treatment was continued adding the clindamycin, the mean ASO value was found to be higher $(p=0.001)$. It was determined that the total medical treatment and intravenous treatment periods were longer in patients taking intravenous clindamycin $(p<0.001$ and $p<0.001)$. There was no significant difference between the age of the patients and the duration of intravenous treatment $(p=0.122)$ while the median value of the

Table 2. Hospitalization and control laboratory values of the patients

\begin{tabular}{|c|c|c|c|}
\hline & $\begin{array}{c}\text { Hospitalization } \\
\text { Mean } \pm \text { standard deviation } \\
\text { (min-max) }\end{array}$ & $\begin{array}{l}\text { Day } 4 \text { control of treatment } \\
\text { Mean } \pm \text { standard deviation } \\
\text { (min-max) }\end{array}$ & $\mathbf{p}$ \\
\hline White blood cell count $/ \mathrm{mm}^{3}$ & $\begin{array}{c}11.981 \pm 4.233 \\
\text { (min-maks: } 3.500-25.670)\end{array}$ & $\begin{array}{c}7.086 .2 \pm 2.604 .44 \\
\text { (min-maks: } 2.600-17.200)\end{array}$ & $<0.001$ \\
\hline Platelets $/ \mathrm{mm}^{3}$ & $\begin{array}{c}332.938 \pm 105.758 \\
\text { (min-maks: } 150.000-721.000) \\
\end{array}$ & $\begin{array}{c}348.223 \pm 103.426 \\
\text { (min-maks: } 162.000-662.000)\end{array}$ & 0.014 \\
\hline CRP (mg/L) & $\begin{array}{c}35.2 \pm 39.4 \\
\text { (min-maks: } 2-212 \text { ) }\end{array}$ & $\begin{array}{c}9.2 \pm 10 \\
\text { (min-maks: } 1-62 \mathrm{mg} / \mathrm{L})\end{array}$ & 0.001 \\
\hline $\mathrm{ESH}$ (mm/saat) & $\begin{array}{c}29.1 \pm 17.6 \\
\text { (min-maks: } 2-86)\end{array}$ & $\begin{array}{c}32.2 \pm 18.6 \\
\text { (min-maks: } 2-88)\end{array}$ & 0.264 \\
\hline
\end{tabular}


Table 3. Intravenous (IV) antibiotics used in hospital

\begin{tabular}{|l|c|c|}
\hline Antibiotics (intravenous) & $\mathbf{n}$ & $\mathbf{\%}$ \\
\hline Ampicillin-sulbactam & 82 & 83.7 \\
\hline Ampicillin-sulbactam + clindamycin & 12 & 12.2 \\
\hline Cefuroxime sodium (IV) + clindamycin & 2 & 2.0 \\
\hline Ampicillin-sulbactam + vancomycin & 1 & 1.0 \\
\hline Ceftriaxone + clindamycin & 1 & 1.0 \\
\hline
\end{tabular}

Table 4. Oral antibiotics used after discharge

\begin{tabular}{|l|c|c|}
\hline Sequential antibiotics (oral) & n & \% \\
\hline Amoxicillin-clavulonic acid & 86 & 87.8 \\
\hline Amoxicillin-clavulonic acid + clindamycin & 8 & 8.2 \\
\hline Ampicillin-sulbactam & 2 & 2.0 \\
\hline Cefuroxime axetil (oral) + clindamycin & 2 & 2.0 \\
\hline
\end{tabular}

total treatment duration was found to be longer in children older than 10 years $(p=0.014)$. No significant relationship was found between the presence of fever and intravenous therapy and total treatment duration $(p=0.524$ and $p=0.982$, respectively). As the number of white blood cells of the patients at the time of admission increased, the duration of intravenous treatment was found to have weak correlation and this duration was significantly extended $(r=0.212$ and $p=0.036)$. However; there was no significant correlation between the number of white blood cells at the time of admission and total treatment duration $(p=0.158)$. While there was no significant relationship between the high CRP level at the time of admission and the duration of intravenous treatment $(p=0.137)$, total treatment duration was found to be longer as the CRP level increased ( $p=$ 0.032). Total ESH and ASO values at the time of admission and the duration of total treatment and intravenous treatment did not change. There was no significant relationship between the localization of dental abscess and the duration of total medical treatment and intravenous therapy. After discharge, 63 (64.3\%) patients did not apply to our dentist for dental treatment. Thirty-four (34.7\%) patients underwent tooth extraction in our hospital after the end of the treatment, and $1(1 \%)$ of the patients had the canal treatment and filling for caries in another center.

\section{Discussion}

Oral and dental problems can have a negative impact on the psychosocial health of children, affecting the daily performance of them. In addition, dental caries can lead to nutritional deficiencies that may affect adult health $(8,9)$. The 2020 global goals of the World Health Organization (WHO) on oral and dental health that is a key factor for quality of life have been determined. Accordingly, the goals and standards of oral and dental health were determined according to regional, national and local conditions and it was aimed to reduce the negative effects of oral and dental infections on health and psychosocial development. For this purpose, it is recommended by WHO that dental education in primary education schools and kindergartens should be provided (10). In our country; in 2004, according to the oral dental health study conducted in adults and elderly; It was determined that $4.9 \%$ of the individuals between the ages of $35-44$ did not go to any dentist, $88.2 \%$ of those who went stated that they consulted to the doctor when they had complaints, and the rate of those who regularly went for the control to dentists was $1.1 \%$ (11). In recent years, although the number of permanent caries in the world has decreased gradually, $80 \%$ of all children have been reported to have dental caries at the time of finishing high school (12). In our country, one of every two children who started to primary school has permanent dental caries and the number of dental caries increases after the age group of 14-15 (13). Childhood is critical for having healthy mouth and teeth and ensuring that healthy lifestyle behaviors continue in adulthood. Improvement of oral dental health is possible with the implementation of protective programs for society in pediatric age groups. These protective services mainly consist of oral hygiene training, diet regulation and some special applications. Teeth brushing, which is part of mechanical oral cleaning, should be started at approximately the sixth month after the eruption of the primary teeth. After the eruption of the teeth, brushing should be performed with a clean gauze after the age of 1-1.5, and with a soft tooth brush without toothpaste after the age of 1.5. Child toothpastes with reduced fluorine concentration after age 3 may also be used. One of the preventive oral health measures is the regulation of the diet of children. The most noticeable part of the diet after the eruption of the teeth is related to the use of sugar (14). In our study, the age that the patients started to brush their teeth was quite high and the number of the patients who brushed their teeth regularly was low. There was no patient going to the dentist regularly without a complaint. Almost all of our patients consumed sugary food at least once a day. According to data of 2014 Health Education and Health Manpower Status Report in Turkey, the total number of dentists is 21.160 and the total number of physicians is 129.383 as of December 2013 (15). As suggested by the 2014 American Pediatric Dentistry Association Guideline, it may be beneficial that healthcare workers, including pediatricians, are trained in risk factors for tooth caries and take an active role in these approaches to protect oral and dental health (16).

If dental caries are not treated properly, it may cause to the dentoalveolar abscess and cellulite over time, spreading to the surrounding connective tissue (12). If the odontogenic facial cellulite is not treated properly, it may lead to complications such as sepsis, dehydration, central nervous system infection 
and airway obstruction (6). In studies conducted on the pediatric patients with odontogenic facial cellulitis, it was found that it was more common in males as in our study $(7,17)$. There are also studies showing that tooth-induced cellulite has similar rates in boys and girls $(5,6)$. It has been reported that dental abscess and facial cellulitis are more common in school-age children than in younger age group (5-7). Similarly, in our study, it was found that the majority of the patients consisted of school aged children 5-10 years.

In the management of facial cellulite seen in childhood, it was thought to be useful to determine the location of the infection $(7,17)$. In a retrospective study of 376 facial cellulitis patients in a six-year period, $63(16.7 \%)$ of the patients had a diagnosis of odontogenic cellulitis and $56 \%$ of these patients had involvement in the upper half of the face (12). In adult age group, it is reported that there are infections in the mandibular area and the lower half of the face is involved (18). Similar to other studies, in our study which included pediatric patients with the diagnosis of odontogenic facial cellulitis, the upper face half of the patients was more comman involved $(7,12,17)$.

It was thought that the follow-up of leukocyte count, thrombocyte count, CRP and ESR levels in the follow-up of dental abscess may be an indicator of the duration of hospitalazitaion, the course of local infection, focal and systemic complications $(7,18,19)$. In our study, after the third day of intravenous therapy, that the mean number of white blood cells and CRP levels decreased significantly compared to baseline values was deemded to be an indicator of the response ot the treatment. Although the mean leukocyte count and CRP levels decreased, the increase in mean platelet count was thought to be associated with that thrombocytosis was a late acute phase reactant (19). In a retrospective study on 157 patients with odontogenic maxillofacial infection, the median age of the patients was 31 years (range 2 years-79 years), the median hospitalization duration was 5 days (1-23 days) and the reasons affecting the length of the hospitalization period were to be older than 18 years of age and leukocytosis (18). In a study involving 108 children with facial cellulitis in our country; the mean age was $7.2 \pm 3.2$, mean hospitalization duration was $5.86 \pm 3.38$ days and the reasons causing the duration of hospitalization to shorten were tooth extraction in the first 48 hours and not having leukocytosis. It was found that the duration of hospitalization was longer in patients with cellulitis in lower jaw (7). In our study, the duration of hospitalization was similar to other pediatric studies $(6,7)$. In our study, it was found that the high number of white blood cells prolonged the length of hospitalization, the high level of initial CRP did not affect the length of hospitalization, but it was related to the prolongation of the total treatment duration with consecutive treatment, the total treatment period was longer in children over 10 years and the location of the dental infection does not affect the duration of treatment.
Dental infections are related to the anaerobic and aerobic flora bacteria in the mouth and are generally polymicrobial ( 7 , 20). Often, orofacial cellulitis and abscesses are caused by streptococcal infection. Rarely, odontogenic facial cellulitis may also be caused by the Group A Streptococcal infection (GAS) $(20,21)$. In the human body, GAS produces some extracellular antigens such as streptolysin $\mathrm{O}$, which can induce an antibody response. An increase in ASO titer can be used as an indicator of previous GAS infection. In clinical practice, the timing of a GAS infection is unknown with a single ASO measurement (22). However, as in our study, in patients with progressive findings under standard treatment for soft tissue infections, considering the invasive GAS, clindamycin may be added to the treatment of toxin suppressive effects. In our study, it was found that the patients who had clindamycin added to their treatment had higher ASO titers. Both total and intravenous treatment durations of these patients were longer.

The management of dental infections includes the detection of the infection focus with the detailed examination of the patient and the necessary surgical intervention with the anatomical evaluation and appropriate antibiotic treatment. Empirical treatment in dental infections is based on the estimation of the possible pathogen. The preferred antimicrobial agent should be effective against gram-positive and anaerobic bacteria (20). Although penicillins are effective against both anaerobic and gram positive bacteria, penicillins combinated with beta-lactamase inhibition (ampicillin-sulbactam, amoxicillin-clavulonic acid) are a good option in odontogenic cellulitis due to beta-lactamase enzyme production of oral anaerobic bacteria in childhood (23). In patients allergic to penicillin, antibiotics other than beta-lactam are recommended if there is a history of allergy in the form of anaphylactic reaction. Clindamycin is a good option in the presence of a history of penicillin allergy, especially in outpatients $(7,17,20)$. The necessity of surgical removal of the source of infection in the treatment should be evaluated by the dentist (20). In our study, it was found that nearly $90 \%$ of penicillins combinated with beta-lactamase inhibitor used as the first choice in empirical treatment were effective. The choice of antibiotic therapy in dental infections should be selected taking into account the patient's medical history, antibiotic activity, safety and cost of the drug. In dentistry practice, penicillin or ampicillin use resulted in treatment success of about $97 \%$ and no combination therapy was required (20). Indications for combination therapy are limited in the practice of pediatric infectious diseases according to the principles of rational antibiotic use. In our study, it was thought that both the stimulation of resistance development and unnecessary cost were prevented by the high rate of treatment success obtained without the use of combined antibiotic therapy with a broader effect spectrum. 


\section{Conclusion}

As a result, it is very important to maintain tooth-brushing habits at an early age to prevent oral tooth health, which is an integral part of the general health of the individual, to avoid the foods that cause tooth caries and to maintain the dental health protective behaviors through regular dentist follow-ups. In childhood, dental caries may progress, if not recognized early, and may cause facial cellulitis and, in particular, hospitalization in school-age children. Factors influencing the duration of hospitalization and total treatment duration include the patient's age, peripheral white blood cell count, and CRP elevation; Peripheral white blood cell and CRP course are useful in evaluating the response to treatment. Treatment with penicillins combinated with beta-lactamase inhibitor is successful.

Ethics Committe Approval: The study was approved by the Ethics Committee of Keçiören Education and Research Hospital Ethics Committee with the resolution number 2018/1651.

Informed Consent: Written informed consent was not recieved due to retrospective nature of this study.

Peer-review: Externally peer-reviewed.

Author Contributions: Concept - AK, TAT; Design - GT, GiB; Supervision - FNÖ, GT, ÖMA; Data Collection and/or Processing - AK, SYD, ÖMA, ZGGA, GiB; Analysis and/or Interpretation - GT, AK, TAT; Literature Review - AK, TAT, GT; Writing - AK, GT, TAT; Critical Review - AK, GT, TAT, FNÖ, GIB

Conflict of Interest: The authors have not reported a conflict of interest.

Financial Disclosure: There is no financial support in this study.

\section{References}

1. Alsumait A, EISalhy $M$, Raine $K$, et al. Impact of dental health on children's oral health-related quality of life: a cross-sectional study. Health Qual Life Outcomes 2015;13:98.

2. Shaw J. Infections of the oral cavity. In: Long SS, Prober CG, Fischer $M$ (eds). Principles and Practice of Pediatric Infectious Diseases. Philadelphia: 2018:193-9.

3. QuickStats: Prevalence of Untreated Dental Caries in Permanent Teeth Among Children and Adolescents Aged 6-19 Years, by Age Group National Health and Nutrition Examination Survey, United States, 2011-2014. MMWR Morb Mortal Wkly Rep 2017;66:36.

4. Sağlıkistatistikleri Yıllığı2016. T.C. Sağlık Bakanlığı. Sağlık Araştırmaları Genel Müdürlüğü. Bölüm 3: Morbitide. Ankara, 2016:31-47.
5. Gonçalves L, Lauriti L, Yamamoto MK, Luz JG. Characteristics and management of patients requiring hospitalization for treatment of odontogenic infections. J Craniofac Surg 2013;24:e458-62.

6. Lin YT, Lu PW. Retrospective study of pediatric facial cellulitis of odontogenic origin. Pediatr Infect Dis J 2006;25:339-42.

7. Kara A, Ozsurekci $Y$, Tekcicek $M$, et al. Length of hospital stay and management of facial cellulitis of odontogenic origin in children. Pediatr Dent 2014; 36:18E-22E.

8. Ferraz NK, Nogueira LC, Pinheiro ML, Marques LS, Ramos-Jorge ML, Ramos-Jorge J. Clinical consequences of untreated dental caries and toothache in preschool children. Pediatr Dent 2014;36:389-92.

9. Gurunathan D, Shanmugaavel AK. Dental neglect among children in Chennai. J Indian Soc Pedod Prev Dent 2016;34:364-9.

10. Hobdell $M$, Petersen PE, Clarkson J, Johnson N. Global goals for oral health 2020. Int Dent J 2003;53:285-8.

11. Gökalp S, Güçiz Doğan B, Tekçiçek M, Berberoğlu A, Ünlüer Ş. Erişkin ve yaşlılarda ağız-diş sağlığı profili Türkiye-2004. Hacettepe Diş Hekimliği Dergisi 2007;31:11-8

12. Thikkurissy S, Rawlins JT, Kumar A, Evans E, Casamassimo PS. Rapid treatment reduces hospitalization for pediatric patients with odontogenic-based cellulitis. Am J Emerg Med 2010; 28:668-72.

13. Yurdasal B, Bozkurt Al, Öz I, Tanrıverdi S, Taş E, Nalbant M. Denizli Ağız Diş Sağığını Geliştirme Projesi; 3. Yıl Sonuçları. Turkish Journal Of Public Health 2012:10:44-52.

14. Akar Ç. Türkiye'de ağız-diş sağlığı hizmetlerinin strateji değerlendirmesi. Ankara: Türk Dişhekimleri Birliği Yayınları, Araştırma Dizisi: 9, 2014.

15. Türkiye'de Sağlık Eğitimi ve Sağlık Insangücü Durum Raporu-2014. Solak M (editor). Eşkişehir 2014.

16. American Academy of Pediatric Dentistry. Guideline on caries-risk assessment and management for infants, children, and adolescents. Pediatr Dent 2013;35:E157-64.

17. Dodson TB, Perrott $D H$, Kaban LB. Pediatric maxillofacial infections: a retrospective study of 113 patients. J Oral Maxillofac Surg 1989;47:32730.

18. Wang J, Ahani A, Pogrel MA. A five-year retrospective study of odontogenic maxillofacial infections in a large urban public hospital. Int J Oral Maxillofac Surg 2005;34:646-9.

19. Long SS, Vodzak J. Laboratory manifestations of infectious diseases. In: Long SS, Prober CG, Fischer M (eds). Principles and Practice of Pediatric Infectious Diseases. 5th edition. Philadelphia: Elsevier Inc, 2018:144759.

20. Holmes $C J$, Pellecchia R. Antimicrobial therapy in management of odontogenic infections in general dentistry. Dent Clin North Am 2016;60:497-507.

21. Rega AJ, Aziz SR, Ziccardi VB. Microbiology and antibiotic sensitivities of head and neck space infections of odontogenic origin. J Oral Maxillofac Surg 2006;64:1377-80.

22. Sen ES, Ramanan AV. How to use antistreptolysin O titre. Arch Dis Child Educ Pract Ed 2014;99:231-8.

23. Holmberg P, Hellmich $T$, Homme J. Pediatric sepsis secondary to an occult dental abscess: a case report. J Emerg Med 2017;52:744-8. 